\title{
Department of reconstructive surgery, Armed Forces Medical College, Pune
}

\author{
B. B. Dogra \\ Department of Plastic and Reconstructive Surgery, AFMC, Pune, India
}

Address for correspondence: Col B. B. Dogra, Prof and Head, Dept of Plastic and Reconstructive Surgery, Armed Forces Medical College, Pune - 411040, India. E-mail: drbbdogra@yahoo.co.in

\section{INTRODUCTION}

$\mathrm{t}$ is a matter of great pride and satisfaction for me to be bestowed this singular honor of penning down the history of, undoubtedly, the oldest department where plastic surgery was practiced in our country in the good old days dating back to the Second World War. The history of plastic surgery in India in general and in our Armed Forces in particular is closely linked to the history of the Armed Forces Medical College.

It was during the Second World War in February 1942, when it was initially discussed by a group of Special Medical Personnel Mission at the Southern Command Headquarters to set up an institute on the lines of the Royal Army Medical College Milbank, UK. The site proposed was at the R A Barracks, at Khadkee but this did not materialize.

However, in July 1942, tents were pitched at Pune for this purpose and the rudiments of AFMC were thus born. On April 3, 1943, the grouping together of the Indian Hospital Corps and the Indian Medical Services formed the Indian Army Medical Corps (IAMC). After many deliberations, it was decided to establish an Army Medical Training Centre (AMTC) at Pune.

However, it was not until the Armed Forces Medical Services and Research Committee was formulated under the able guidance of Dr. BC Roy that the foundation of AFMC was laid. On May 1, 1948, the Armed Forces Medical College was formed by the fusion of the Army Medical Training Centre, the Medical Research Organisation, the Central Medical Pathology Lab, the Army Transfusion
Centre and the Central Army School of Radiology. This was the humble beginning of perhaps the only medical Institution in the world where postgraduate courses preceded undergraduate facilities.

As far as the plastic surgery service in the Indian Armed Forces is concerned, it dates back to the post Second World War period. In 1945, two Indian maxillofacial surgical units were established. The No. 1 unit was at Khadkee near Pune under Dr Fitzgibbon and later under Dr. Gibson. The No. 2 unit was at Secunderabad under Mr Eric Peet. In 1946, Capt (Dr) C. Balakrishnan was posted at the No. 1 unit. This Maxillofacial Surgery unit in Khadkee was designated as 7-IBGH, where plastic surgery was first started in our country. Capt (Dr) C. Balakrishanan and Capt (Dr) B. R. Sukh were the first trainees in plastic surgery and were initiated into plastic surgery by $\mathrm{Dr}$ Gibson and Mr. E. W. Peet in this unit.

Capt (Dr.) R. Ganguly, who later became the famous plastic surgeon from the army, was a trainee in General Surgery in the same hospital during the Second World War days. Capt (Dr.) C. Balakrishanan was an emergency commissioned officer with the Indian Army who decided to hang his uniform after the contractual period. After Independence in 1947, he went to England to receive further training in plastic surgery where he had the opportunity to work with such stalwarts as Prof TP Kilner and Sir Harold Gillies.

Capt C. Balakrishnan returned back from the UK in 1950 and he joined Government Medical College Nagpur as a lecturer and was instrumental in starting the Nagpur Plastic Surgery Centre. However Capt BR Sukh continued Indian J Plast Surg January-June 2005 Vol 38 Issue 1 
in the Army and he went to Yugoslavia, took training in plastic surgery there for nine months and on his return started the first formal Plastic Surgery Unit in the Armed Forces at the Military Hospital in Pune in 1955.

Sir Harold Gillies visited this center during his first trip to India in 1955 and greatly appreciated the beautiful tube flaps raised by Maj. BR Sukh. In the same year, the Govt. of India invited Sir B. K. Rank, from the Royal Melbourne Hospital Australia, to advice on the development of plastic surgery in India. He welcomed the idea of forming a plastic surgery section of The Association of Surgeons of India.

In 1957 Sir Harold Gillies visited India again. During this visit to Pune, he demonstrated various operations and techniques. He visited and lectured at several centers in various parts of country, namely Kolkata, Delhi, Patna, Jaipur and lastly Nagpur where he formally inaugurated the plastic surgery section of The Association of Surgeons of India.

In the meantime, Maj.. Rasamay Ganguly [Figure 1] had gone to the UK for obtaining training in vascular surgery at King's College Hospital London and retuned to India. He happened to meet the Director, Medical Services Army, Lt Gen BM Rao at the Military Hospital Kolkata, who enquired as to what surgical experience he had gathered during his study leave at UK. Gen Rao was especially interested if Maj.. Ganguly had received any training in plastic surgery and casually told him to take over the plastic surgery unit at the Command Hospital Pune from Maj. BR Sukh who was posted out to Delhi. Since Dr.

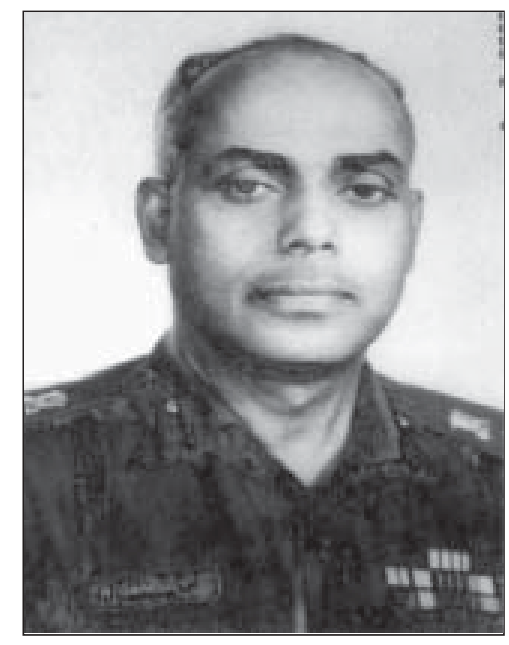

Figure 1: Lt Col Rasamay Ganguly, VSM
Ganguly was not formally trained in plastic surgery, he was initially quite reluctant to take over this commitment but had to agree when Gen BM Rao told him that he had earmarked him to take over the Plastic Surgery unit in the Command Hospital Pune.

In the year 1960, the Association of Surgeons of India decided to hold their Annual Conference at Pune in December 1960 and this meeting was organized partly in the AFMC and partly at BJ Medical College Pune. A very interesting incident happened during this conference, which I would like to share with you all. It so happened that Maj. Ganguly was asked by Col Joseph, Prof of Surgery AFMC to arrange a ward round for the visiting delegates in Command Hospital Pune. Maj. Ganguly selected a variety of interesting cases from different wards including a few from plastic surgery, which he had tackled in his own way. One of the foreign visitors was quite interested to see the plastic surgery cases, and during the tea break this foreign visitor called Maj. Ganguly aside and wanted to know where he had received his training in the specialty. When Maj. Ganguly told him proudly that he was a self-trained plastic surgeon, this foreign visitor casually remarked that he could see that from the cases demonstrated. This foreign visitor was none else than Sir BK Rank, the pioneering plastic surgeon from Melbourne, Australia. Dr Rank promised to arrange a senior fellowship for his training in Plastic Surgery under the Colombo plan in Australia. Accordingly, Maj. Ganguly went to Australia in July 1961 and worked there under Sir BK Rank in the Royal Melbourne Hospital and under Mr. Wakefield, a consultant plastic surgeon at the Royal Children Hospital. On his return from Australia, Lt Col Ganguly was posted to Command Hospital Pune where he remodeled the operation theatre, physiotherapy department, burns unit and started a separate outpatient department for Reconstructive Surgery cases in a separate barrack.

The Indo-Pak war of 1965 brought to Pune a large number of war casualties which required various reconstructive surgical procedures. A need was felt at this juncture to train another plastic surgeon and Maj. PML Kathpalia [Figure 2] came over as the first trainee in reconstructive surgery at this center. Maj. HRP Sinha closely followed him and Maj. SK Acharya joined as a trainee in 1968. Maj. Kathpalia subsequently went to Australia and got trained under Sir BK Rank and on his return was posted to the Command Hospital Central Command Lucknow and established a plastic surgery center at the Command 


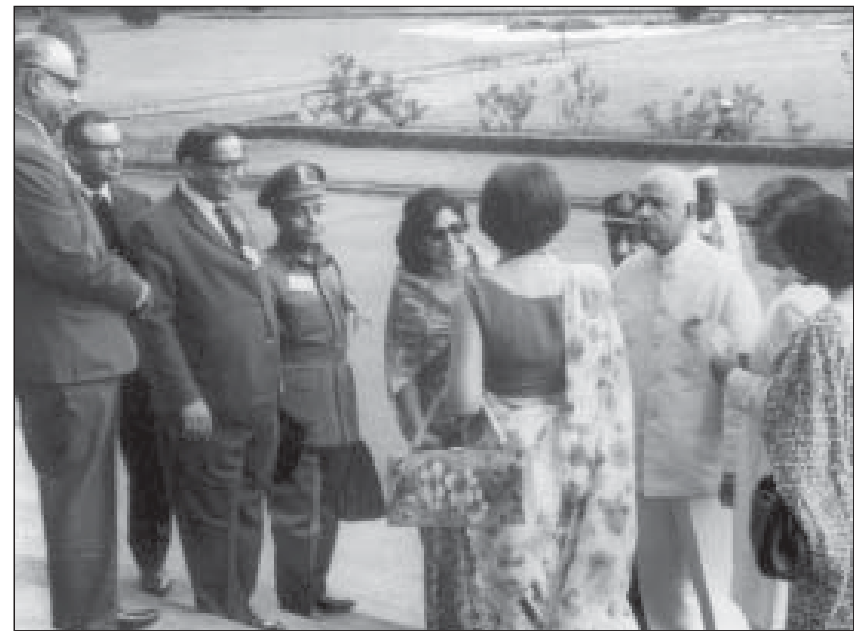

Figure 2: His Excellency Mr Kurian Governor of Maharashtra and Dr. Rafiq Zakaria Health Minister arriving at AFMC Pune for inauguration ceremony of Apsicon-1968

\section{Hospital Lucknow.}

On the suggestion of Dr. NH Antia, the President of the Association of Plastic Surgeons of India for the year 1968, the annual conference of the APSI was held in AFMC. This conference was inaugurated by His Excellency Mr. Kurian, Governor of Maharashtra, and Dr. Rafiq Zakaria, Health Minister of Maharashtra was a special invitee (Figure 3). A photo exhibition of the reconstructive surgery carried out in the Command Hospital Pune was arranged in the conference room of the college building and Col Ganguly delivered the welcome address in the college auditorium.

On December 3, 1971, another Indo-Pak war broke out on the Eastern as well as the Western Front. The Indian Army along with the Mukti Bahini marched into East

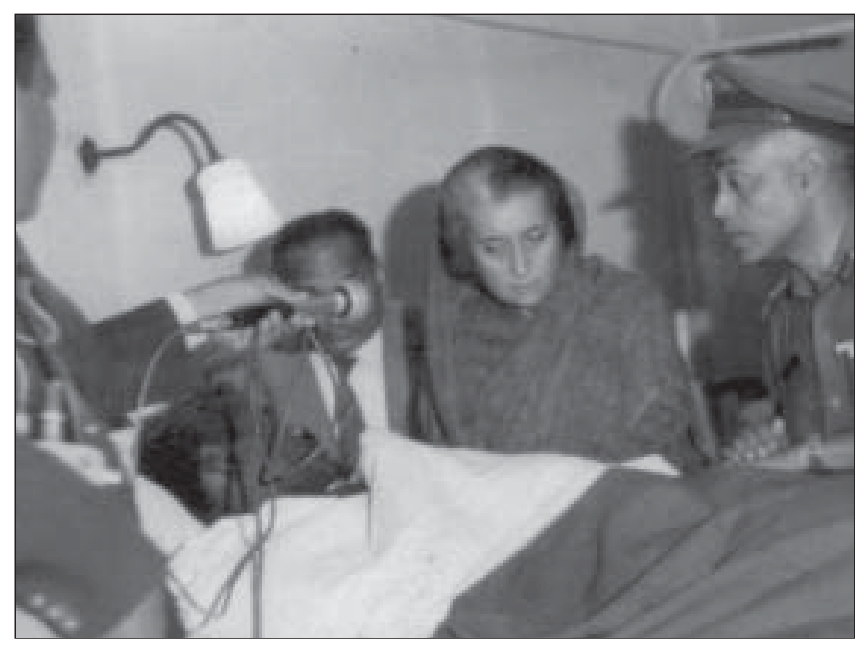

Figure 3: Mrs Indira Gandhi, Prime Minister of India meeting the wounded soldiers at the reconstructive surgery ward at Command Hospital Pune during 1971 Indo-Pak War
Pakistan and Bangladesh was created. A large number of battle casualties including Mukti Bahini militia were evacuated to this center for various reconstructive surgical procedures and rehabilitation. Mrs. Indira Gandhi, Prime Minister, visited the wounded Jawans in our hospital to boost their morale [Figure 4].

Col Rasamay Ganguly later delivered the prestigious Dr. BC Roy Memorial Oration for the year 1972 and the subject he chose for this oration was "Reconstructive Surgery in Injuries of War".

Another feather in the history of the Department of Plastic surgery, Command Hospital and AFMC Pune, was added in 1973 when formal training for MCh in Plastic Surgery was started here and Lt Col HRP Sinha [Figure 5] took over as first Professor and Head of the Department of Plastic Surgery in 1973. Dr Uttam Khare was the first MCh student in Plastic Surgery from this college under the University of Pune. Col Sinha was a teacher par excellence and a dedicated plastic surgeon. He continued as head of the department for almost four years and was posted to Command Hospital (Eastern Command) Kolkata in 1977 where he established another plastic surgery and burns center. Mother Theresa inaugurated this burns center in 1977.

Another brilliant officer Col NC Sanyal succeeded Col Sinha at the Command Hospital and AFMC Pune. Col Sanyal was a highly popular teacher and a brilliant surgeon who was instrumental in updating the department with newer equipments and a separate 10 -bedded burn unit was created in the family wing complex during his tenure

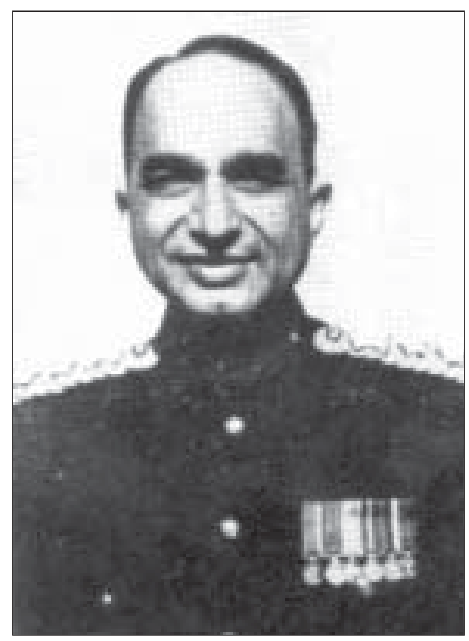

Figure 4: Col PML Kathpalia- First student from this department Indian J Plast Surg January-June 2005 Vol 38 Issue 1 
from 1977 to 1983 . He trained almost half a dozen MCh students. Col NC Sanyal was the first plastic surgeon who started myocutaneous flaps in the armed forces and won the coveted "Peet Prize" for his paper on myocutaneous flaps. For his utmost dedication and hard work he rose to the pinnacle of glory and was the first plastic surgeon to be the Director General, Armed Forces Medical Services in the rank of Lt Gen and was also honored by The Association of Plastic Surgeons of India by choosing him as President of the Association for the year 1990.

Col Ashim Banerjee succeeded Col Sanyal as Prof and HOD. He has the singular distinction of being the only service plastic surgeon having a $\mathrm{PhD}$ in plastic surgery. He was also the first plastic surgeon from the services who got trained as a microvascular surgeon. He had a brilliant academic career but for personal reasons he chose to take premature retirement from service and a brilliant service career was interrupted in 1986 .

Col Ashim Banerjee was followed by Col JC Sharma to occupy the coveted chair of Professor and HOD. Col Sharma was trained at Lucknow and obtained his MCh degree from KGMC Lucknow. He subsequently went to England and worked with Mr. Piggott and was Fellow of the Royal College of Surgeons of England. He pioneered craniofacial surgery in the armed forces and took very active part in repair and reconstruction in battle casualties during "OP PAWAN" in Sri Lanka. He rose to the topmost post in the naval services and retired as Director General Medical Services Navy. The Association of Plastic Surgeons also gave due recognition of his contributions to the specialty and he was President of the Association for the year 1996.

Col YG Tambay succeeded Col JC Sharma and was Professor and HOD Plastic Surgery from 1991 till 1993. He was the first MCh student of this department to occupy this exalted chair. He went to the UK to obtain special training in hand surgery and had the opportunity to work with such luminaries as Dr. Lamb.
Col Luxmi Prasad Sadhotra, a graduate of Medical College Srinagar who obtained his $\mathrm{MCh}$ in plastic surgery from PGI in Chandigarh was another plastic surgeon who was instrumental in renovating the department and started microvascular surgery on a regular basis in our department. He stressed the importance of inculcating microvascular training during the MCh training period and hence created a micro-lab in the department and all MCh trainees are now exposed to microvascular training during their MCh. Col Sadhotra was HOD from 1997 to November 2000 . He is presently heading the most prestigious hospital of the armed forces-Army Hospital (Research and Referral) at Delhi.

The present incumbent, Col BB Dogra, another graduate of Medical College Srinagar joined the department as HOD on July 3, 2001. He did his MCh Plastic Surgery from this institute under the Pune University in 1989. He has streamlined all the training and departmental activities and record-keeping. Three computers with peripherals including a digital camera and a handycam have been added. This has helped materially in raising the levels and standards of all facets of training, record-keeping, archiving and presentations and publications from the department. A large number of instruments and sophisticated equipment have also been added.

We hosted a National Continuing Medical Education Programme 10-11 April 2004, which was very well attended by distinguished guest speakers from across the country and MCh students from all over Maharashtra.

There are three Pune University recognized teachers in the department, namely Lt Col Manmohan Singh and Lt Col Bijitesh Chakravarty besides Col BB Dogra. We take one MCh student every year as per MCI guidelines after an entrance exam for which service candidates as well as civilian candidates compete. Twenty-five surgeons including six from civilian background have been successfully trained for their MCh Plastic Surgery degree from this department till date. 